\title{
Indigenous Education: A Powerful Tool for Value Promotion in Nigeria
}

\author{
Sharhabilu Umar \\ Department of Educational Foundations \\ Shehu Shagari College of Education Sokoto, Sokoto State,Nigeria \\ Murtala Hussaini Shagari \\ Department of Islamic Studies \\ Shehu Shagari College of Education Sokoto, Sokoto State,Nigeria
}

\section{Doi:10.5901/mjss.2013.v4n12p9}

\begin{abstract}
Before the advent of colonial administration in Nigeria, Nigerians had their own kind of education, which was indigenous, in this system, every member of the society displayed the value of the system. Thus, honesty, respect, patriotism, communalism, hard work and so forth become characteristic hallmark of every member of the society. This paper, therefore, examines Nigeria's values that have given way to the value of money, comfort and easiness. It traces the root cause of this value disorientation to lopsided attention which Mankind pays to scientific and technological development that brings with it material gain and neglect of value development training, it concluded by recommending that value developments education should be include, curriculum of education at all levels, likewise parents should be role models for their children and Information Communication Technology (ICT) education should include value education and value education website should be established on the net among others.
\end{abstract}

\section{Introduction}

In every given society, education, be it formal, non-formal and indigenous is as old as existence. Sociologically, education plays a significant role in every human life. For an individual to be useful in society, every member of society must be equipped with a specific education in order to be a useful member, a role model and a man of a good character.

The paper hold that every sane being and of course institution or organization strives to teach his/her younger generation acceptable norms, attitudes, behaviours and values that make life meaningful and manageable for maximum profitability and positive interaction and integration. The above note withstanding in recent times, there has been public out cry over the problem of value disorientation. Orderly behaviour, moral respect and hard work have given way to the value of money, comfort and easiness. Most Nigerian value preferences are in a state of confusion. Youth today are growing up in a world that at times seems frightening. Mba and Uchendu (2007).

In support of the view expressed above, Igbo, Okpenga and Ako (2007) said "for any nation to develop meaningfully, her citizen must cultivate good values" in recent times, there has been general public out city over the decaying value standards, selfish and undesirable values have replace wholesome ones that lead to healthy development. Perhaps, the scholar that hits the nail on the head is Ukeje (1999). In Anyebe (2011). He said "Unfortunately, the Nigerian decay is particularly grave, debilitating, degenerating, deteriorating and dehumanizing in regard to education, our institutions of learning where we ought to breed youths of high value have becomes dens of robbers, campus prostitutes, cultists, 419ners, examinations malpractice culprits, internet fraud stars and a host of other unwholesome characters that are alien to our culture." 


\section{Meaning of Education}

There is no universally acceptable definition of education, many definitions of education exist as a result of different schools of thought. However, education can be described as a complex process and network of activities through which society familiarizes the new born with acceptable norms of the society Noah, (1997). In the same vain Bolarin (2007), defines education as the process of transmission of the values and accumulated knowledge of society. In other words, it is a social process which neither ends in classroom nor with formal schooling. That means, education requires value reorientation process which an individual needs to acquire through her life time for effective adulthood in the society.

Education according to Okolo (2009) in Okolo (2011). Is a vehicle for social change and unavoidable means of physical, social, political, religious, moral development for lifelong learning and survival. Education is what is worthwhile to those who are committed to it be they children or adults.

\section{The Concept of Value}

The word value is so important to human life, human existence and interaction that so many scholars have different definitions. Kazi (2002) in Anyebe (2011) "it is not easy to define value to the test of every body. This is because of its relativity to individuals, time circumstance and location, however in the context of social studies education". Fraenkel (1973) as quoted in Anyebu (2011) defines value as constituting a number of deeply held ideas of commitments by an individual which have bearing on his actions or behaviours in the society.

To the psychologists, values are what an individual or society holds to be right, true and desirable. They are widely held or sentiments that some activities, relationships teachings are essential to the community or social well-being. Value according to the academic's dictionary of education stands for ideas men live for, values are part and parcel of the philosophy of a nation and the educational system. Values are the guiding principles which enable us to be healthy, and to make suitable adjustment with our own culture, according to it. An educationist has said "value are concepts heavily weighted with emotions. They are concepts of desirable type which influence the child's selection from available models, means and ends of action. Because they are primarily subjective, they are stronger predispositions of behaviour than concepts, with less heavy emotional weightage". Values include all important religious beliefs, moral attitudes, philosophies of life, political ideologies etc which help in sustaining the society and its culture. They also help in bringing about the corresponding changes in the society and culture.

The implication of all the definitions above is that values are essential for national development and harmonious living, values vary from one society to another, value is of importance to ethical, psychological and sociological discourse because it affects thoughts, feelings, behaviours, attitude, choice and goals, value is therefore, a standard that directs one's behaviour towards achieving ones desired goals.

\section{Indispensability of Indigenous Education for Value Promoting in Nigeria Society}

The departure from desirable values to undesirable values calls for serious attention. Education is the only hope Nigeria has in promoting her lost glory. The effort of our ancestors that set out the cherished values and undesirable values cannot be overemphasized. Oderinde (2004) in Okolo (2011) lamented that what is happening in and outside the school and indeed the larger society for the past two decades indicates that there is serious missing gap in the inculcation of values in Nigerian schools at all levels of educations. He further stressed that, the home, school and government attitude towards the desirable values in the society contributed immensely to decadences of earlier cherished socio-cultural values.

In the other hand, the type of education being practiced all over Africa before the arrival of western education was basically referred to as indigenous education. Fafunwa (1974) defines indigenous education 
as

"the aggregate of all process by which a child develops his abilities, attitudes and other forms of behaviour which are of positive value to the society in which he intend to lives".

The system consist of teaching and learning which every individual undergoes throughout their life time, (Aderounmi \& Ibeh, 1984). In Dosunmo (2011) it was a life long process, related to the environment, to assist individuals with saleable skills practical and functional. Indigenous system of education took an unorganized setting, with no classrooms and the curriculum was unstructured. In other words, the learning activities took place every where and every adult was a teacher to the child. Significantly, the system emphasized humanity, human dignity, respect, honesty while communalism was the basic principle of everybody in the society.

The indigenous or informal system of education assisted a growing child to have interaction with several people, acquire a vast amount of knowledge and function in a given society. The child learned the value of the society as well as the 'dos and don'ts ' of the society and that assisted the child to become a useful member of the society and at the end, the same child reorientate the young ones with the values acquires in the society.

Indigenous education is expected to produce an individual who will be honest, respectable, skilled, cooperative and a conformist to the norms and values of the society, Fafunwa (1974) listed seven cardinal goals of such African education as follows:

1. Development of the child's physical skills

2. Character and moral training

3. Development of intellectual and social skills

4. To acquire specific vocational training and to develop a healthy attitude towards honest labour

5. To inculcate respect for elders and those in position of authority

6. To understand, appreciate and promote the cultural heritage of the community at large. However, Africa indigenous system of education has a wide curriculum for the realization of it's objectives in order to produce a well nutured individual who will be useful to himself and the community at large. Thus, practical orientation and functionalism are the hallmarks of the system. Sociologically, the growing child is prepared to be honest, respectable, acquire skills, cooperative and so on. In doing this, it prepared the child for his/her adulthood and make him/her to become a useful member to the society at large. Thus, the concept of honest, respect, patriotism are values that must be upheld. In indigenous system of education, every member of the society is expected to display honesty, respect, transparency, accountability, patriotism and failure of all these may not be regarded as a man of good character.

7. Development of sense of belonging, the child is taught from the beginning the homogenous nature of the community. He is told that every one is his brother's keeper. All important cultural heritage is taught to the child. He participate actively on every community project such as clearing the village square. He watches the naming ceremonies, funeral ceremonies, coronation ceremonies and pick the appropriate roles expected of him. Conformity to the cultural norms of the society certifies a child as well educated.

\section{How Indigenous Education Can be Used as Tool to Promote Value}

Education is a process of imparting skills, attitudes, knowledge and values in learners. It is a potent medium for transmitting the needed skills, used in achieving quality development of peace and tolerance in Nigeria.

There are two types of education. There are formal and informal. The informal one is the type that takes place mostly at home without an organized time table and curriculum. Usually, it is in the family that this type of education take place. 
Odoemelam and Okafor (2005) as quoted in Anyebe (2011) asserted that it is the duty of the family to inculcate the expected values and attitude into the child. These values according to them are honesty, patriotism, love, obedience, unity, work habit, positive attitudes to life and good leadership quality. However, the unfortunate thing is that presently the family seems to have lost a grip of the above cherished values. For instance the family which should provide models are characterized by corruption, selfishness, greediness, lawliness among others Nwosu (2004).

Still on the family as an agent of value transmitter, Igbo, Egbe, Okpenge and Akor (2007) in Anyebe (2011) observed that, "the family is the smallest unit of society and its role in inculcating values to social learning theories like Bandura according to them believe that the child learns values through imitations of parents, siblings and other members of the family at home during early childhood upbringing".

Nwobi (1997) in discussing, the role of the parents on value inculcation asserted that parents who are immoral are not likely to instill high moral standards in their children. They can never give what they do not have to their children.

\section{Recommendations}

* Parents should be role models for their offspring

* There should be value education website on the internet

* Honesty, hard work and integrity should always be renewed in our schools and society

* Value development education should be included in the curriculum of education at all levels in Nigeria

* Teachers, lecturers, politicians and leaders in different professions must present themselves as role models

\section{Conclusion}

Education and value are two inseparable concepts, without education, value cannot be imbibed, for a child, a youth, a learner or even a citizen to acculturate value, there must be skills and knowledge, there must be one form of education or the other, informal and formal. The informal one is the type that takes place mostly at home without an organized time-table and curriculum, it is in the family that this type of education take place, in view of this, parents, teachers as well as stakeholders should all inculcate appropriate values into their wards as this will helps the learners to value their culture, adhere to their principles and standards of the society: this can also be achieved through inculcating indigenous system of education, which will be useful to the citizen in all sphares of life.

\section{References}

Aderounmu, O. and Ibeh, E. (1984). In Dosunmu, S. (2011). The Need for Value Re-orientation through enhancement of indigenous education in Nigeria, Book of reading. Vol. 1. pp. 131-137 Hoom-Bethakz Publishers.

Bellingham, J. (2008). Academic's Dictionary of Education. Academic (India) publishers.

Bolarin, T. A. (2007). History of education in Africa, Ibadan Olu-Akin publishers.

Fafunwa, A. B. (1974) . history of education in Nigeria, London George Allen and Unwin.

Igbo, H. I Egbe-Okpenge t.d \& Ako J. A. (2007). In Anyebe, M. Conference proceeding. Book of reading October, 2011, ASEN publication.

Kazi, D. (2002). The Seope of Social studies education Jos: WAIS printing press.

Mbah, M. N \& Uchenda, O. G (2007). Strategies for inculcating value in the youth in Anyebe, M. (2011) education: a Tool for Value Promotion in Nigeria. ASEN Publication Vol. 1 pp 56-64

Noah, A. O. K. (1997). In Pemede, O. (2011). The growth and development of education in Lagos State. General studies: Book of Reading (Ed). Vol. 2. 126-145, Lagos state University press. 
Oderinde, B. B. (2004). Preface and Acknowledgement in values of education. Journal of the Nigeria Academy of Education.

Okolo, A. N. (2009). In Okolo, A. N. (2011). Education, value re-orientation and the rebranding process of Nigeria Vol. 1 pp 60-68. ASEN publication.

Okeje, B. O. (1999). Teacher education in Nigeria current status in Anyebe, education: A Tool for Value Promotion in Nigeria, October (2011) vol.1 pp 56-64. 
